\title{
Effect of a Monensin Controlled-Release Capsule on Rumen and Blood Metabolites in Florida Holstein Transition Cows*
}

\author{
P. Melendez, ${ }^{1}$ J. P. Goff, ${ }^{2}$ C. A. Risco, ${ }^{1}$ L. F. Archbald,${ }^{1}$ R. Littell, ${ }^{3}$ and G. A. Donovan ${ }^{1}$ \\ ${ }^{1}$ College of Veterinary Medicine, University of Florida, Gainesville, 32610 \\ ${ }^{2}$ National Animal Research Center, USDA, Ames, IA \\ ${ }^{3}$ Insitute of Food and Agriculture Sciences, University of Florida, Gainesville, 32610
}

\section{ABSTRACT}

The objective of this study was to determine the effect of a monensin controlled-release capsule administered intraruminally at dry-off on rumen volatile fatty acids, $\mathrm{NH}_{3}$, lactate, $\mathrm{pH}$, and energy blood metabolites in transition dairy cows fed Florida typical diets. In March 2003, 24 cows (10 primiparous and 14 multiparous) dried-off 50 to $70 \mathrm{~d}$ before expected parturition were randomly assigned to a treatment $(\mathrm{n}=12$, oral capsule of monensin) or a control group ( $n=12$, no capsule). Both groups received the same diet and were exposed to the same environment and management conditions. At assignment, at $21 \mathrm{~d}$ before expected parturition, at calving, and at 7, 14, and $21 \mathrm{~d}$ postpartum, blood samples were taken and body condition scores were determined. At $10 \mathrm{~d}$ postpartum, rumen and blood samples were obtained in the morning before the first feeding and at 2,4 , and $6 \mathrm{~h}$ after feeding. Serum nonesterified fatty acids (NEFA), $\beta$-hydroxybutyrate (BHBA), and glucose were measured. Rumen samples were analyzed for concentrations of acetic, propionic, butyric, L- and D-lactic acids, and $\mathrm{NH}_{3}$. Data for rumen and blood metabolites were analyzed by ANOVA, mixed models for repeated measures. Volatile fatty acids were not different between groups. Multiparous treated cows had a significant reduction in rumen $\mathrm{NH}_{3}$ at $6 \mathrm{~h}$ after feeding. Treatment with monensin significantly increased body condition score at calving in multiparous cows. During the postpartum period, NEFA and BHBA were noticeably lower in treated than in control primiparous cows. This difference was not observed in multiparous cows. (Key words: monensin, volatile fatty acid, rumen $\mathrm{pH}$, transition cow)

Abbreviation key: BEP = before expected parturition, DCAD = dietary cation-anion difference, $\mathbf{P P}=$ postpartum.

\footnotetext{
Received June 8, 2004

Accepted August 11, 2004.

Corresponding author: G. A. Donovan; e-mail: donovana@mail. vetmed.ufl.edu.

*Published as journal series number R-10485 of the Florida Agricultural Experiment Station.
}

\section{INTRODUCTION}

Monensin is an ionophore that alters the rumen microflora, which results in an increase in the molar proportion of propionic acid with a concurrent decrease in the molar proportion of acetate and butyrate in the rumen (Richardson et al., 1976). The increase in rumen propionate is accompanied by a reduction in methane production in the rumen, an increase in blood glucose level, and a decline in the incidence of ketosis and related disorders (Nagaraja et al., 1997; Duffield et al., 1998b, 1999). Monensin also decreases L-lactate concentrations (Callaway and Martin, 1997; Nagaraja et al., 1997) and affects nitrogen metabolism by decreasing rumen ammonia production in cattle fed different diets (Yang and Russell, 1993; Nagaraja et al., 1997).

Monensin has been available for use in food animals for more than $20 \mathrm{yr}$. However, limited information is available about its effect in lactating dairy cows. In the last $10 \mathrm{yr}$, several studies have been conducted in Canada and Australia using monensin in a controlledrelease capsule in transition dairy cows (Stephenson et al., 1997; Duffield et al., 1998a; Green et al., 1999; Mutsvangwa et al., 2002). The use of monensin is not currently permitted in lactating dairy cows in the United States.

Citrus pulp is an energy concentrate by-product rich in pectin and is a common component of dairy cattle diets in Florida and other southern states (Arthington et al., 2002). Bacteria that ferment pectin are gramnegative and resist the action of monensin (Nagaraja et al., 1997). Hypothetically, this bacterial population would not be altered by monensin; therefore the pectin fermentation dynamic would not change and monensin would still affect other rumen microorganisms influencing the molar proportion of $\mathrm{VFA}, \mathrm{NH}_{3}$, lactate, rumen $\mathrm{pH}$, and blood metabolites in transition Holstein cows fed typical Florida diets.

Therefore, the objective of the present study was to determine the effect of a monensin controlled-release capsule administered intraruminally at dry-off on the molar proportion of VFA, $\mathrm{NH}_{3}$, lactate, rumen $\mathrm{pH}$, and energy-related blood metabolites in Florida transition cows fed diets containing citrus pulp. 
Table 1. Diet composition of dry cow far-off, dry cow transition, and lactating transition cows.

\begin{tabular}{llcl}
\hline Feed & $\begin{array}{l}\text { Dry cows } \\
\text { far-off }\end{array}$ & $\begin{array}{l}\text { Dry cows } \\
\text { transition }\end{array}$ & $\begin{array}{l}\text { Lactating } \\
\text { transition }\end{array}$ \\
\hline Alfalfa hay & $\ldots$ & 18.00 & 10.54 \\
Coastal hay & 16.82 & 2.24 & 10.08 \\
Corn silage & 22.17 & 25.60 & 28.32 \\
Ryegrass silage & 22.50 & 9.88 & $\ldots$. \\
Corn hominy & 7.22 & 9.14 & 16.96 \\
Citrus pulp & 5.20 & 7.18 & 7.84 \\
Soybean meal 48 & 5.56 & 8.68 & 12.35 \\
Wet brewers grain & 8.79 & 7.71 & 5.61 \\
Soyhull pellet & 8.30 & 7.28 & 5.40 \\
Lactowhey & 1.93 & $\ldots$. & $\ldots$ \\
Springer minerals & $\ldots$ & 4.29 & $\ldots$ \\
Dry cow minerals & 1.51 & $\ldots$. & $\ldots$ \\
Lactating minerals & $\ldots$ & $\ldots$ & 2.90 \\
\hline
\end{tabular}

${ }^{1}$ Ammoniated whey $(61.5 \% \mathrm{CP})$.

\section{MATERIALS AND METHODS}

\section{Cows and Herd Management}

The study was conducted on a commercial Holstein dairy farm milking 3000 cows $3 \times$ with a milk rolling herd average of $10,700 \mathrm{~kg}$. The farm is located in north central Florida (Bell, FL). Lactating cows were housed in a dry-lot system and fed the same TMR 3 times a day, except postpartum (PP) transition cows, which received a diet higher in forage NDF. Cows were driedoff between 50 to $70 \mathrm{~d}$ before expected parturition (BEP) and maintained in a dry-lot until $21 \mathrm{~d}$ BEP. They were fed a typical Florida dry cow diet (Tables 1 and 2). Transition prepartum cows (from $21 \mathrm{~d}$ BEP to calving) were housed in a dry-lot with adequate feed-bunk space, water, and shade. They received, twice a day, a TMR containing citrus pulp with a dietary cation-anion difference (DCAD) of $-58.5 \mathrm{mEq} / \mathrm{kg}$ of DM using the equation DCAD $(\mathrm{mEq})=(\mathrm{Na}+\mathrm{K})-(\mathrm{Cl}+\mathrm{S})($ Tables 1 and 2). After calving, cows were moved from the processing pen to a PP lot and fed a fresh diet until $21 \mathrm{~d}$ in milk (Tables 1 and 2).

\section{Experimental Protocol}

This study was approved by the Institutional Animal Care \& Use Committee of the University of Florida, and the Food and Drug Administration.

In March 2003, 24 cows dried-off 50 to $70 \mathrm{~d}$ BEP were randomly (computer-generated table) assigned to a treatment or a control group. Cows in the treatment group ( $\mathrm{n}=12 ; 5$ primiparous, 7 multiparous) received orally a capsule of monensin releasing approximately $335 \mathrm{mg}$ of monensin daily for $95 \mathrm{~d}$ (CRC Rumensin, Elanco Animal Health, Guelph, Canada). Control cows (no capsule, $\mathrm{n}=12 ; 5$ primiparous, 7 multiparous) were randomly matched by parity. The number of animals
Table 2. Nutrient content of dry cow far-off, dry cow transition, and lactating transition diets.

\begin{tabular}{|c|c|c|c|}
\hline Nutrient & $\begin{array}{l}\text { Dry cow } \\
\text { far-off }\end{array}$ & $\begin{array}{l}\text { Dry cow } \\
\text { transition }\end{array}$ & $\begin{array}{l}\text { Lactating } \\
\text { transition }\end{array}$ \\
\hline $\mathrm{CP}(\% \text { of } \mathrm{DM})^{1}$ & 15.52 & 17.83 & 18.70 \\
\hline Undegradable protein $(\% \text { of } \mathrm{CP})^{2}$ & 26.38 & 34.35 & 31.34 \\
\hline Degradable protein $(\% \text { of } \mathrm{CP})^{2}$ & 73.62 & 65.65 & 68.66 \\
\hline Soluble protein $(\% \text { of } \mathrm{CP})^{2}$ & $\ldots$ & 35.72 & 38.77 \\
\hline $\mathrm{NE}_{\mathrm{L}}(\mathrm{Mcal} / \mathrm{kg})^{3}$ & 0.84 & 1.67 & 1.69 \\
\hline $\mathrm{ADF}(\% \text { of } \mathrm{DM})^{1}$ & 24.54 & 24.13 & 23.70 \\
\hline $\mathrm{NDF}(\% \text { of } \mathrm{DM})^{1}$ & 36.04 & 35.20 & 34.53 \\
\hline $\mathrm{NFC}(\% \text { of } \mathrm{DM})^{2}$ & 32.94 & 32.35 & 34.56 \\
\hline Starch $(\% \text { of DM })^{2}$ & 11.05 & 13.99 & 15.10 \\
\hline Lipid $(\% \text { of DM })^{1}$ & 2.85 & 5.89 & 4.36 \\
\hline $\mathrm{Ca}(\% \text { of } \mathrm{DM})^{1}$ & 0.74 & 1.29 & 1.15 \\
\hline $\mathrm{P}(\% \text { of } \mathrm{DM})^{1}$ & 0.30 & 0.36 & 0.45 \\
\hline $\mathrm{Mg}(\% \text { of } \mathrm{DM})^{1}$ & 0.32 & 0.36 & 0.37 \\
\hline $\mathrm{K}(\% \text { of DM })^{1}$ & 1.28 & 1.12 & 1.48 \\
\hline $\mathrm{Na}(\% \text { of } \mathrm{DM})^{1}$ & 0.09 & 0.09 & 0.56 \\
\hline $\mathrm{Cl}(\% \text { of } \mathrm{DM})^{1}$ & 0.18 & 0.45 & 0.45 \\
\hline $\mathrm{S}(\% \text { of } \mathrm{DM})^{1}$ & 0.24 & 0.41 & 0.21 \\
\hline Forage in diet (\% of DM) & 61.49 & 55.72 & 48.94 \\
\hline Cation-anion $(\mathrm{meq} / \mathrm{kg} \text { of } \mathrm{DM})^{4}$ & 165.90 & -58.50 & 363.10 \\
\hline
\end{tabular}

${ }^{1}$ Laboratory nutritional analysis.

${ }^{2}$ Values from feed composition tables.

${ }^{3}$ From formulas after laboratory analysis.

${ }^{4}$ From formula $\left(\mathrm{Na}^{+}+\mathrm{K}^{+}\right)-\left(\mathrm{Cl}^{-}+\mathrm{S}^{-}\right)$.

per treatment was calculated expecting an increase in rumen molar proportion of propionate from 19 to 22 $\mathrm{mmol} / \mathrm{L}( \pm 1.2)$ (Ramanzin et al., 1997; Ruiz et al., 2001), with $95 \%$ confidence and $80 \%$ of power. Another criterion for sample size justification was the concentration of BHBA at $14 \mathrm{~d}$ PP. With a difference of $100 \mu \mathrm{mol} / \mathrm{L}$ between groups $(\mathrm{SD}=60 \mu \mathrm{mol} / \mathrm{L}$ ) (Duffield et al., 1998a), and with $95 \%$ confidence and $80 \%$ of power, the required sample size was 9 animals per group.

Treated and control cows received the same diet (Tables 1 and 2) and were exposed to the same environment and management conditions during the entire experimental protocol. Primiparous cows were pregnant heifers during their prepartum period that received the same cow diet without anionic salts $(\mathrm{DCAD}=+283$ $\mathrm{mEq} / \mathrm{kg}$ of DM) during 3 wk BEP. Animals were monitored for health problems during the experimental period, and pens were periodically inspected to observe if boluses were regurgitated. No boluses were recorded to be lost.

\section{Blood Sampling and BCS}

At assignment, on d $21 \mathrm{BEP}$, at calving, and at 7, 14, and $21 \mathrm{~d} \mathrm{PP}$, a blood sample was obtained and a BCS evaluation was conducted, at the same time of the day and by the same person. Blood samples were collected from the coccygeal vessels, using an evacuated tube without anticoagulant for serum collection and $\mathrm{NaFl}$ tubes for glucose analysis (Vacutainer, Becton Dickin- 
son, Rutherford, NJ). Body condition score was evaluated at assignment and at calving using a scale of 1 to 5 based on standard methodology (Ferguson et al., 1994).

\section{Rumen and Blood Sampling}

At $10 \mathrm{~d}$ PP, each experimental cow was subjected to a rumen and blood sampling protocol. Each cow was placed in a chute. The blood sample was taken as described previously, before taking the rumen sample. The first rumen sample was obtained at $0700 \mathrm{~h}$, just before receiving the first feeding of the day. A second, third, and fourth sample were obtained at 2 , 4, and 6 $\mathrm{h}$, respectively, after the first feeding (2-h intervals). Rumen samples were taken using a rumen tube sampling device (Jorgensen Laboratories Inc., Loveland, $\mathrm{CO}$ ), based on a previously described technique (Duffield et al., 2004). The distal end of the tube has a weighted metal device that penetrates the rumen mat, allowing collection of a sample from the ventral sac of the rumen. The other end is connected to a manual vacuum pump that aspirates rumen fluid. A volume of approximately $300 \mathrm{~mL}$ of rumen fluid was collected each time. Rumen $\mathrm{pH}$ was measured immediately after taking the sample with an electronic $\mathrm{pH}$ meter (Micro pHep3 waterproof $\mathrm{pH}$ tester, Hannah Instruments, Woonsocket, RI). Twenty milliliters of the ruminal fluid was placed in plastic tubes and $5 \mathrm{~mL}$ of $20 \%$ phosphoric acid was added and mixed with the sample to abruptly cease rumen fermentation. Tubes were sealed and stored at $5^{\circ} \mathrm{C}$ until analysis.

\section{Laboratory Analysis}

Blood samples were centrifuged at $4000 \times g$ for 10 min. Sera were separated and stored in plastic tubes and frozen at $-20^{\circ} \mathrm{C}$ until analysis was performed. Serum NEFA, BHBA, and glucose were measured. Serum NEFA concentration was determined by an enzymaticcolorimetric method (Johnson and Peters, 1993) using a commercial kit (NEFA-C kit WAKO, Saitama, Japan). Serum BHBA concentration was determined by an enzymatic-colorimetric method (Williamson and Mellanby, 1974) using a commercial kit (Pointe Scientific, Inc., Lincoln Park, MI). Glucose concentration was determined using a kit based on the Trinder reaction (Sigma Chemical Co., St. Louis, MO) (Bergmeyer and Bernt, 1974).

Rumen samples were analyzed for concentrations of acetic, propionic, butyric, and L- and D-lactic acids, and $\mathrm{NH}_{3}$. Volatile fatty acid concentrations were determined using gas chromatography separation technique (Supelco Inc., Bellefonte, PA). L- and D-lactate concentrations were determined enzymatically by the L- and
D-lactate dehydrogenase reaction (Olsen, 1962; Ludvigsen et al., 1983) using a microcentrifugal analyzer. Ammonia levels were measured by the glutamate dehydrogenase reaction (Bergmeyer and Beutler, 1985) using a microcentrifugal analyzer.

Bolus administration was conducted by the principal investigator. Subsequently, blood and rumen sampling, laboratory analysis, and BC scoring were performed by the principal investigator who had no knowledge of the treatment status of individual animals.

\section{Statistical Analysis}

The null hypothesis was that there is no difference in the concentration of rumen and blood metabolites between treatment groups. Data for rumen and blood metabolites were analyzed by ANOVA, constructing mixed models for repeated measures with the corresponding covariance structure based on the best goodness-of-fit criteria (Littell et al., 1998). Wilk-Shapiro statistic was used to determine the degree of normal distribution of BCS $(P>0.95)$. This variable was analyzed as continuous in a mixed model for repeated measures. Statistical analysis was conducted using SAS 8.2 (SAS, 2001). The level of significance was established at $P \leq 0.05$. Tendency was considered when the $P$ value was between 0.1 and 0.05 .

Mixed models for repeated measures were defined as:

$$
\begin{aligned}
\mathrm{y}_{\mathrm{ijkl}}=\mu+\mathrm{T}_{\mathrm{i}} & +\operatorname{Cow}\left(\mathrm{T}_{\mathrm{i}}\right)_{\mathrm{j}}+\mathrm{Time}_{\mathrm{k}}+\operatorname{Par}_{1}+(\operatorname{Time} \times \mathrm{T})_{\mathrm{ki}} \\
& +\left(\operatorname{Par} \times \operatorname{Time} \times \mathrm{T}_{\mathrm{kil}}+\mathrm{e}_{\mathrm{ijk}},\right.
\end{aligned}
$$

where $\mathrm{y}_{\mathrm{ijkl}}=$ blood, rumen metabolites, or BCS, $\mathrm{T}_{\mathrm{i}}=$ fixed effect of treatment, Cow $\left(\mathrm{T}_{\mathrm{i}}\right)_{\mathrm{j}}=$ random effect of cow nested in treatment, Time $_{k}=$ fixed effect of time, $\operatorname{Par}_{1}=$ fixed effect of parity, $(\text { Time } \times \mathrm{T})_{\mathrm{ik}}=$ interaction of time and treatment, $(\operatorname{Par} \times \text { Time } \times \mathrm{T})_{\text {kil }}=$ interaction of time, parity, and treatment, and $\mathrm{e}_{\mathrm{ijkl}}=$ random error term.

\section{RESULTS AND DISCUSSION}

All mixed models for repeated measures constructed in the present study provided the best goodness-of-fit (based on Schwarz Bayesian criterion) under the autoregressive covariance structure and the corresponding correlation matrix of the model (Little et al., 1998).

\section{Rumen pH and Metabolites}

In Tables 3 and 4, least square means and standard error of means for rumen $\mathrm{pH}$ and metabolites at $10 \mathrm{~d}$ PP for primiparous and multiparous cows in treated and control groups are shown. Although ororuminal 
Table 3. Least square means \pm SEM for rumen $\mathrm{pH}$, acetate, propionate, butyrate, valerate, total VFA, ammonia, D- and L-lactate, and acetate to propionate ratio by time in primiparous treated $(n=5)$ and control $(n=5)$ cows at $10 \mathrm{~d}$ postpartum.

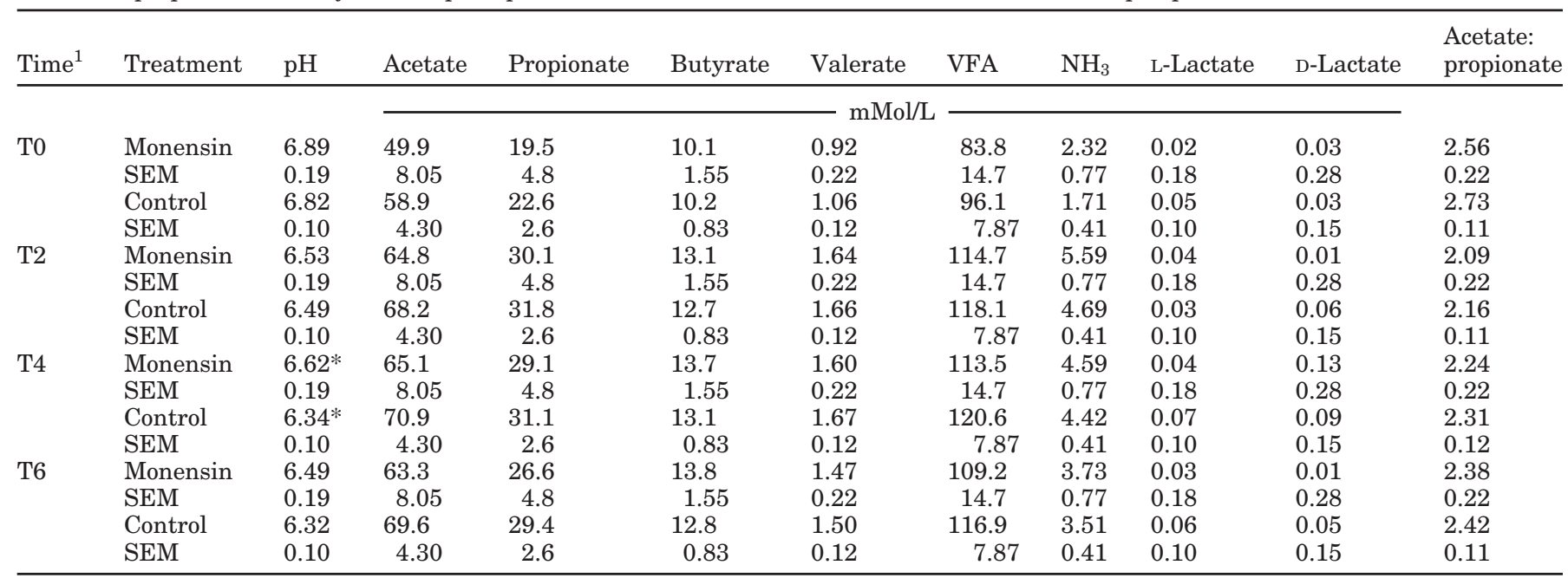

$* P \leq 0.10$.

${ }^{1} \mathrm{~T} 0=0700 \mathrm{~h}$, before feeding; $\mathrm{T} 2=2 \mathrm{~h}$ after a.m. feeding; $\mathrm{T} 4=4 \mathrm{~h}$ after a.m. feeding; $\mathrm{T} 6=6 \mathrm{~h}$ after a.m. feeding.

sampling methodology provides a rumen $\mathrm{pH} 0.3$ to 0.4 units higher than rumenocentesis (Duffield et al., 2004), we were more interested in reporting the changes in rumen $\mathrm{pH}$ between sampling periods than in their absolute values. Primiparous control cows tended to have a lower rumen $\mathrm{pH} 4 \mathrm{~h}$ after feeding than cows treated with monensin (Table $3 ; P \leq 0.1$ ). This may be explained by the fact that monensin prevents the development of rumen acidosis (Nagaraja et al., 1997). However, D- and L-lactate were not statistically different between groups, and were comparable with the re- sults obtained by Mutsvangwa et al. (2002). Other studies did not find differences in rumen $\mathrm{pH}$ in primiparous animals supplemented with monensin (Green et al., 1999). However, when those results were analyzed by treatment effect, the difference in rumen $\mathrm{pH}$ was significantly higher for animals treated with monensin than for controls. There was also a tendency for the interaction parity $\times$ treatment effect $(P=0.11)$, where primiparous treated cows had a higher rumen $\mathrm{pH}$ than primiparous control cows (6.85 vs. 6.50 , respectively). Rumen $\mathrm{pH}$ is a complex end result that cannot only be

Table 4. Least square means $\pm \mathrm{SEM}$ for rumen $\mathrm{pH}$, acetate, propionate, butyrate, valerate, total VFA, $\mathrm{NH}_{3}$, D- and L-lactate, and acetate:propionate ratio by time in multiparous treated $(n=7)$ and control $(n=7)$ cows at $10 \mathrm{~d}$ postpartum.

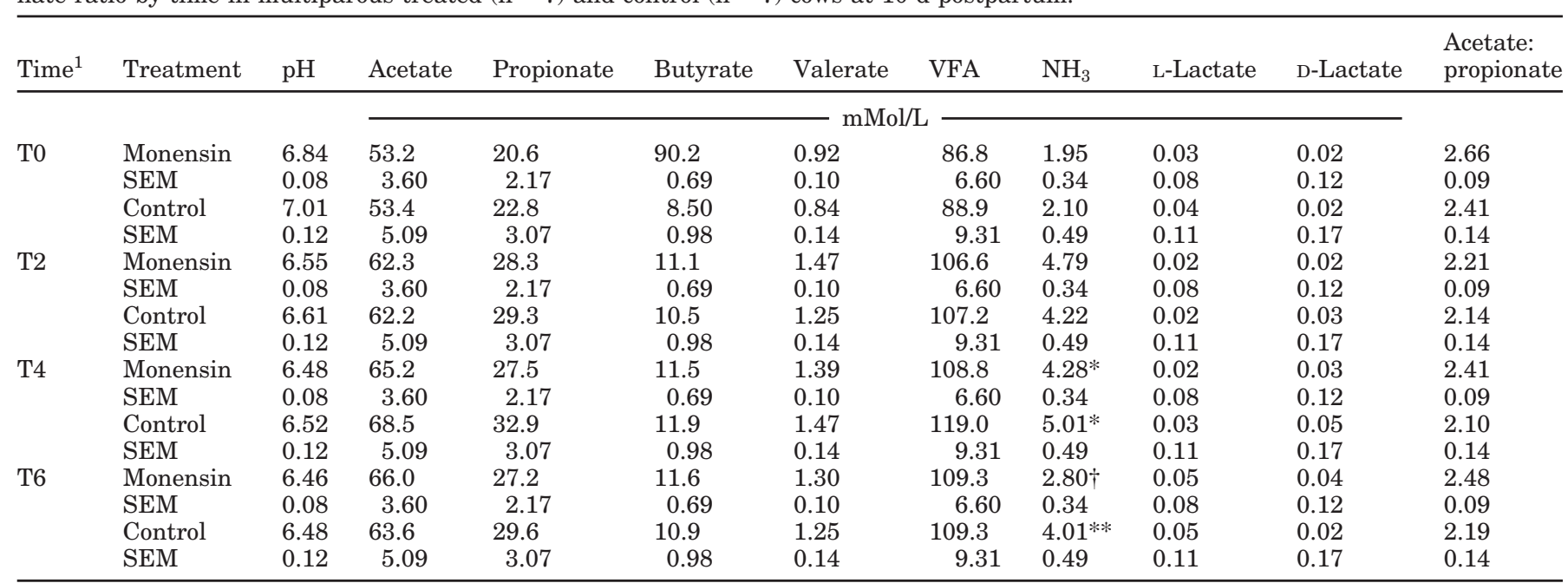

$* P \leq 0.15 ; * * P \leq 0.05)$.

${ }^{1} \mathrm{~T} 0=0700 \mathrm{~h}$, before feeding; T2 $=2 \mathrm{~h}$ after a.m. feeding; $\mathrm{T} 4=4 \mathrm{~h}$ after a.m. feeding; $\mathrm{T} 6=6 \mathrm{~h}$ after a.m. feeding. 
explained by lactate or VFA concentrations, but also by bicarbonate, potassium, and chloride concentrations (Duffield et al., 2004).

Volatile fatty acid concentrations were not different between groups $(P>0.05)$. The lack of significance for VFA might indicate that there was no effect of treatment or that the sample size relative to rumen metabolites may have reduced the power to detect differences due to treatments (power $=60 \%$ or 18 animals per group). The number of animals per group was calculated expecting an increase in rumen molar proportion of propionate from 19 to $22 \pm 1.2 \mathrm{mmol} / \mathrm{L}$ (Ramanzin et al., 1997; Ruiz et al., 2001).

Multiparous cows treated with monensin had a tendency to have lower ammonia concentration at $4 \mathrm{~h}$ after feeding $(P \leq 0.10)$ and had a significant reduction in rumen ammonia at $6 \mathrm{~h}$ after feeding $(P \leq 0.05)$. These findings are consistent with previous research, which showed that monensin caused a significant decrease in ammonia production, probably as a result of reduced proteolysis, degradation of peptides, and deamination of amino acids in the rumen (Yang and Russell, 1993; Nagaraja et al., 1997). Ammonia production by mixed ruminal bacteria under monensin treatment is decreased by more than $30 \%$, and this decrease corresponded to about a 10-fold decrease in the numbers of bacteria that ferment peptides and amino acids as an energy source for growth (Yang and Russell, 1993). Other authors did not find any positive effects of monensin on ammonia production. However, their sample size was only 8 cows or less per group (Ramanzin et al., 1997: Plaizier et al., 2000).

\section{Blood Metabolites and BCS}

At assignment, cows did not differ in BCS, days BEP, parity, or previous lactation mature equivalent milk production $(P>0.05)$. Body condition score changed over time, with an interaction of treatment $\times$ parity. Treatment affected BCS significantly only in multiparous cows (Figure 1; $P \leq 0.01$ ). Perhaps a longer exposure to monensin ( 50 to $70 \mathrm{~d}$ ) increased the daily weight gain and altered the tissue composition in adult cows, favoring the deposition of fat instead of protein. Indeed, daily gains in adult cattle contain more fat, less protein, and less water than daily gain in growing cattle (first lactating cows) (Williams et al., 1989). Furthermore, the positive effect of monensin on daily weight gain in finishing animals has been well documented (Goodrich et al., 1984). Conversely, in the Canadian studies, monensin boluses were administered at $3 \mathrm{wk}$ prepartum, and BCS at calving was not affected by treatment (Duffield et al., 1999; 2003).

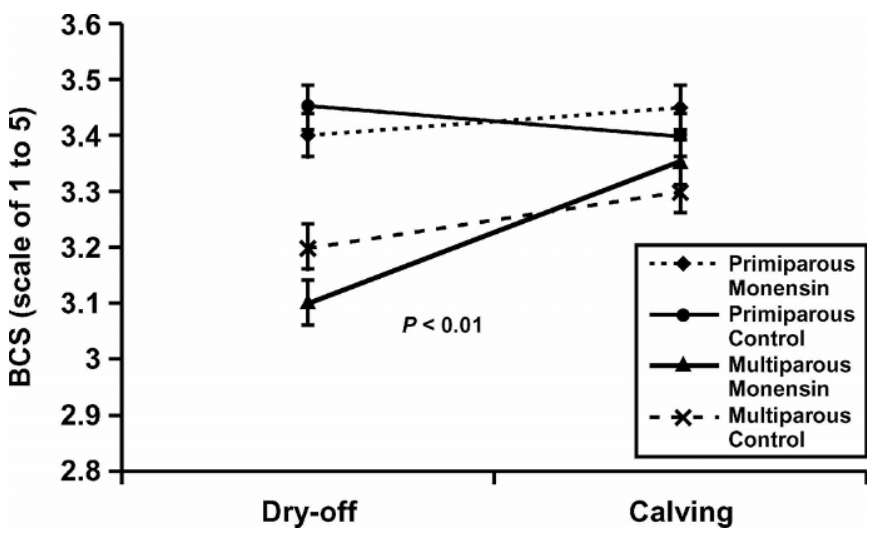

Figure 1. Body condition score at dry-off and at calving in treated and control groups in primiparous $(\mathrm{n}=10)$ and multiparous $(\mathrm{n}=$ 14) cows.

In Figures 2 and 3, blood metabolite concentration dynamics at $10 \mathrm{~d} \mathrm{PP}$ for primiparous and multiparous cows in treated and control groups are illustrated. In Figures 4 and 5, blood metabolite concentration dynamics between dry-off and $21 \mathrm{~d}$ PP for primiparous and multiparous cows in treated and control groups are illustrated.

In general, BHBA and NEFA concentrations were lower and glucose concentrations were higher in the monensin group than in the control group at $10 \mathrm{~d} P \mathrm{PP}$ and during the entire experimental period between dryoff and $21 \mathrm{~d} \mathrm{PP}$, in primiparous and multiparous cows. These results were expected and corroborate findings from other studies that used monensin in a controlledrelease capsule with typical diets high in concentrates (Duffield et al., 1998a,b, 2003; Green et al., 1999) and cows fed on pasture and supplemented with concentrates (Abe et al., 1994; Stephenson et al., 1997). Conversely, Hayes et al. (1996) did not find a positive effect of intraruminal monensin capsules on BHBA, NEFA, and glucose; however, in that study, cows were fed only on pasture with a high content in CP (16.3 to 20.5\% $\mathrm{DM}$ basis) and no concentrate supplementation. Interestingly, independently of treatment, NEFA, BHBA, and glucose increased dramatically at $21 \mathrm{~d}$ prepartum, which indicated that cows around 3 wk prepartum started to change their metabolic status, a condition that has been previously reported (Grum et al., 1996; Drackely, 2001). During the first 3 wk PP, NEFA and BHBA were noticeably lower in treated than in control primiparous cows. This difference was not evident in multiparous cows. Perhaps one of the reasons for this lack of difference was that multiparous cows had lower BCS at calving than primiparous cows, and thus have similar concentrations of NEFA and BHBA during the early PP period. In addition, because treated multipa- 

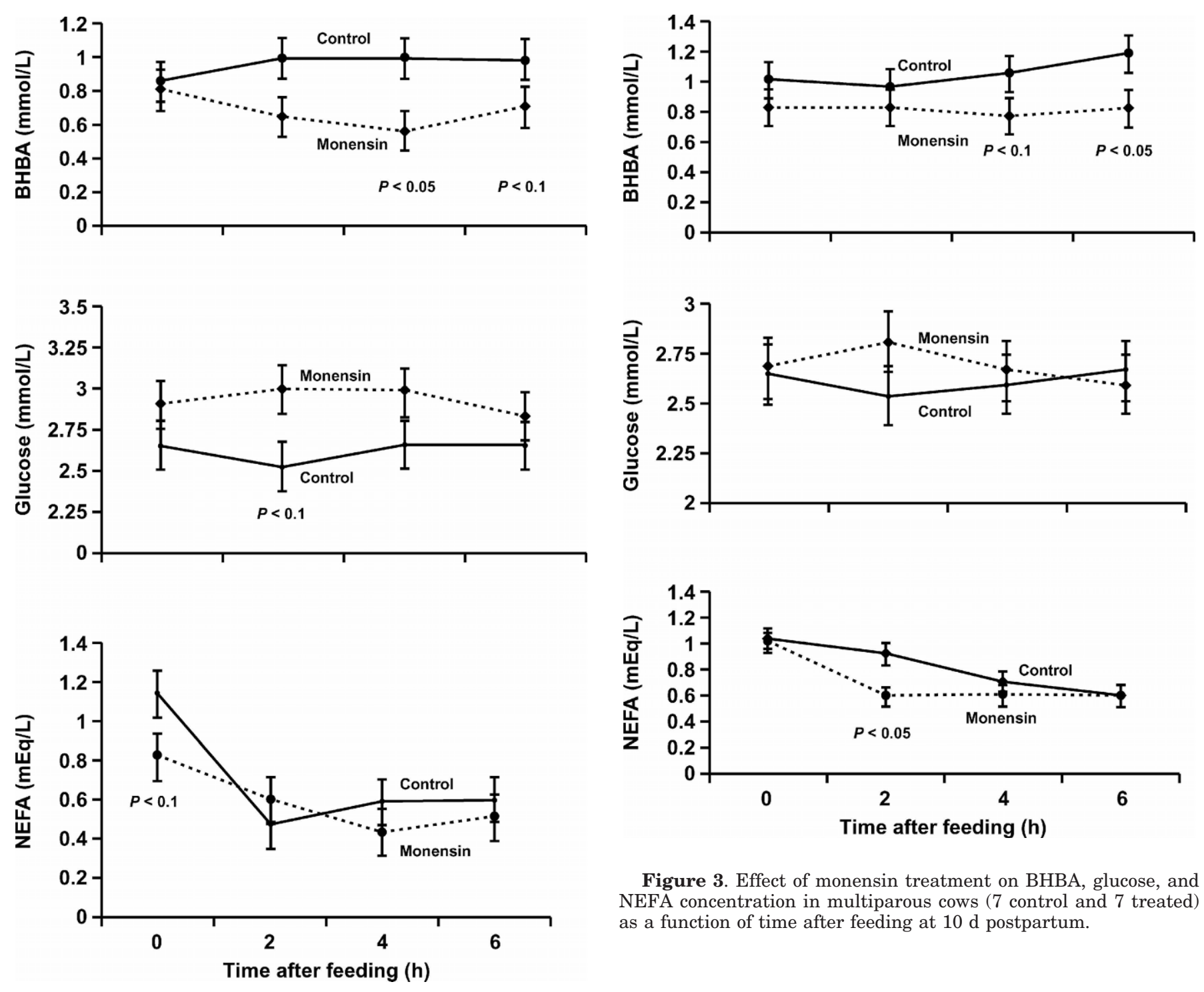

Figure 3. Effect of monensin treatment on BHBA, glucose, and NEFA concentration in multiparous cows ( 7 control and 7 treated) as a function of time after feeding at $10 \mathrm{~d}$ postpartum.

Figure 2. Effect of monensin treatment on BHBA, glucose, and NEFA concentration in primiparous cows (5 control and 5 treated) as a function of time after feeding at $10 \mathrm{~d}$ postpartum.

rous cows had slightly higher BCS at calving than control multiparous cows, they may have exhibited similar concentrations of serum NEFA and BHBA during the early PP, probably because of more mobilization of body fat reserves around parturition than thinner cows.

Differences in hourly metabolite concentrations at 10 $\mathrm{d} P \mathrm{P}$ were more evident in primiparous than in multiparous cows (Figures 2 and 3). These dynamics strongly suggest that monensin had a more positive effect in first-lactation animals than in mature cows. This observation might be apparent because first-lactation cows produce less milk than adult animals. By producing more milk, older cows would experience higher meta-

bolic demands. This condition would worsen if adult cows treated with monensin were higher producers than adult cows not treated with monensin. Under this suggested scenario, metabolic differences should be minimal.

Although rumen fermentation dynamics were shown not to change markedly with treatment, this study demonstrated that cows fed a TMR containing $~ 8 \%$ citrus pulp and supplemented with monensin improved their energy status, as indicated by lower NEFA and BHBA concentrations in blood and higher BCS at calving in multiparous cows. Although monensin boluses were inserted at dry-off (50 to $70 \mathrm{~d} \mathrm{BEP}$ ), monensin still had positive effects on energy status of PP dairy cows at 10 $\mathrm{d}$ of lactation and during the entire period between dryoff and $21 \mathrm{~d} \mathrm{PP}$, confirming the duration of the bolus of $95 \mathrm{~d}$. 

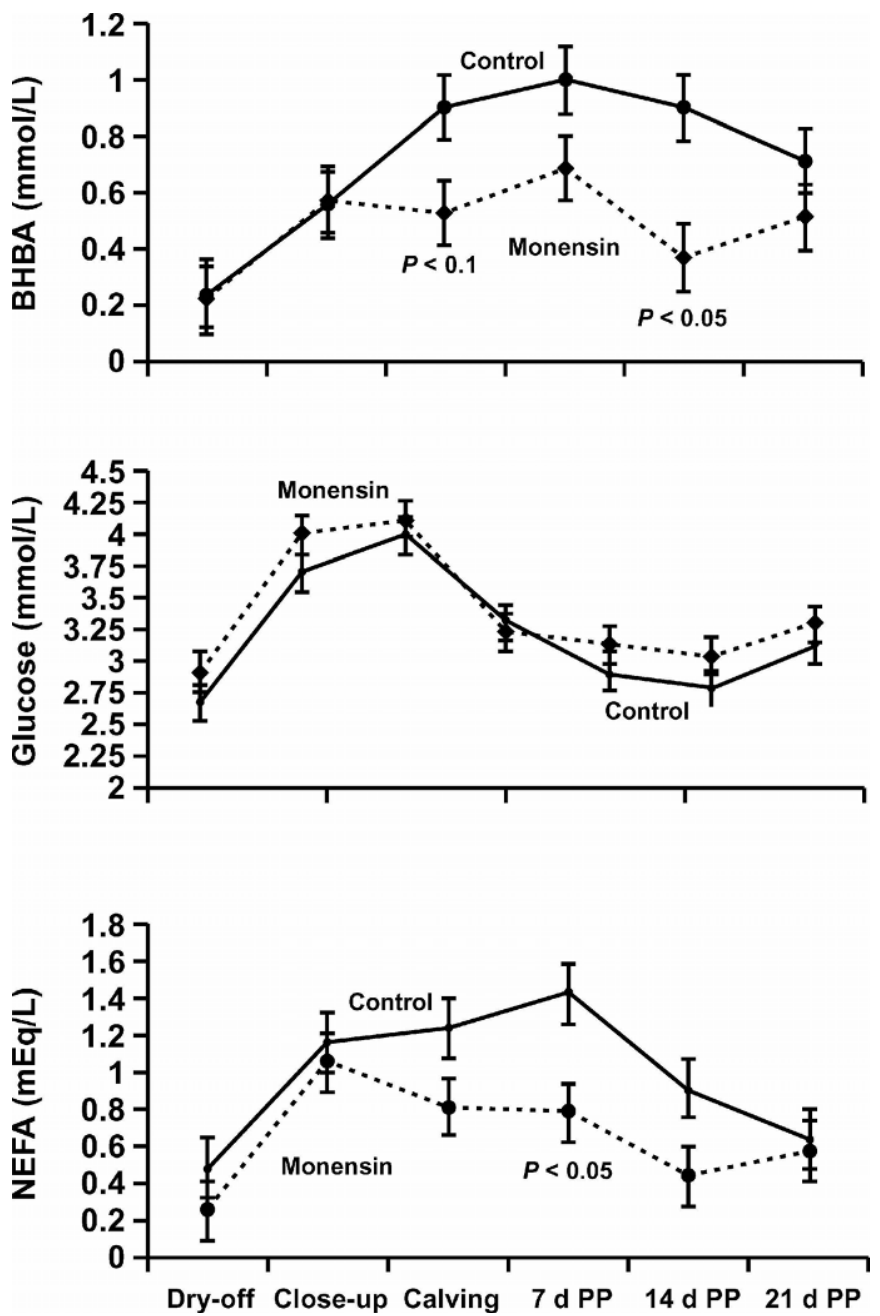

Figure 4. Effect of monensin treatment on BHBA, glucose, and NEFA concentration in primiparous cows ( 5 control and 5 treated) as a function of time. $\mathrm{PP}=$ postpartum.

\section{CONCLUSIONS}

It is concluded that transition cows supplemented with monensin and fed a typical Florida TMR had lower levels of BHBA and NEFA during the entire experimental period and within $6 \mathrm{~h}$ after feeding in primiparous cows. Body condition score at calving was significantly higher in multiparous cows treated with monensin. Minor changes in rumen fermentation were detected under the present experimental conditions.

\section{ACKNOWLEDGMENTS}

The authors thank Shelly Lanhart, Donnald Bennink, the staff of North Florida Holstein, Inc., and veterinary students Chris Sissle and Christina Herejk for their cooperation on this research project. We also thank Leo Richardson and Richard Tucker (Elanco Ani-
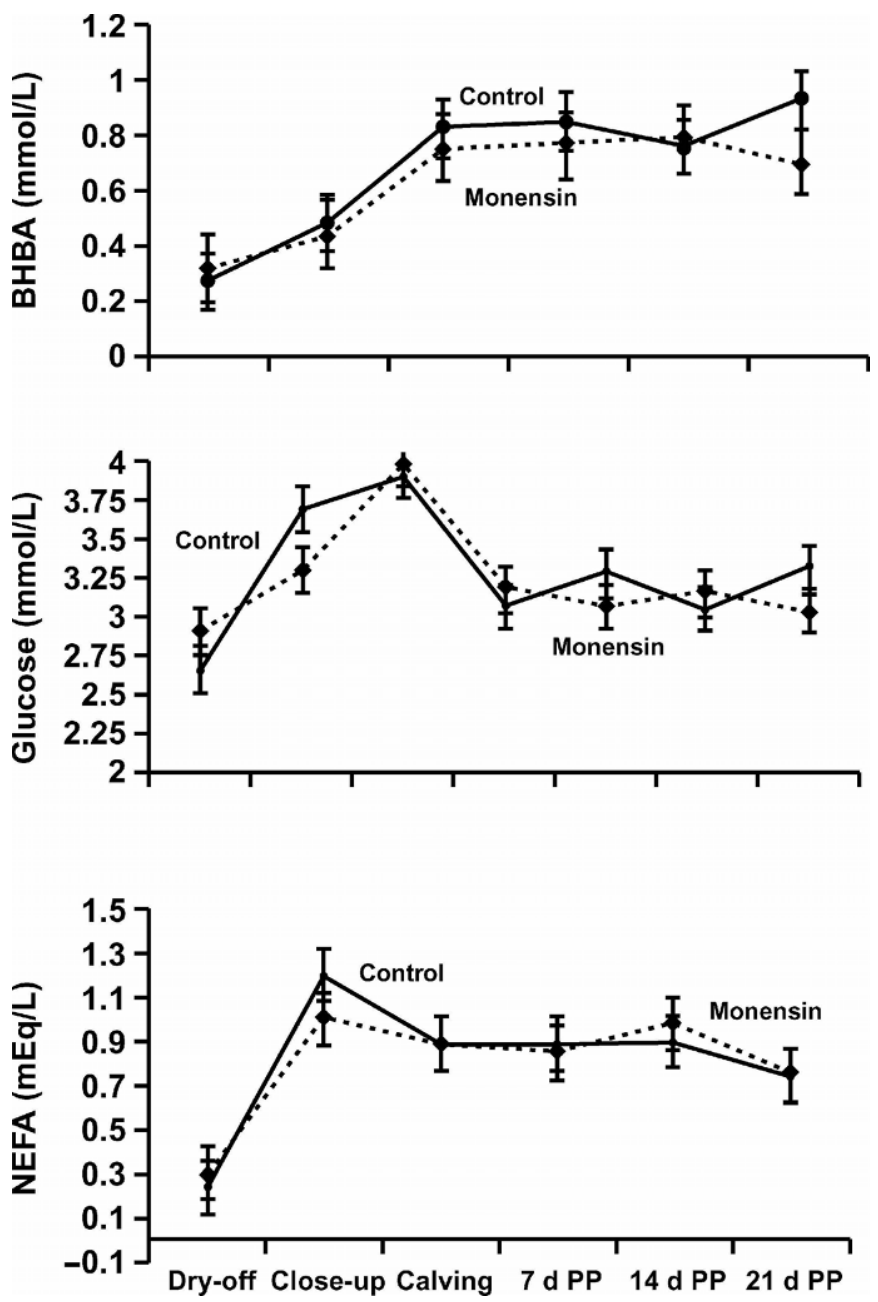

Figure 5. Effect of monensin treatment on BHBA, glucose, and NEFA concentration in multiparous cows ( 7 control and 7 treated) as a function of time. $\mathrm{PP}=$ postpartum.

mal Health) for their support on rumen sample analysis.

\section{REFERENCES}

Abe, N., I. J. Lean, A. Rabiee, J. Porter, and C. Graham. 1994. Effects of sodium monensin on reproductive performance of dairy cattle. II. Effects on metabolites in plasma, resumption of ovarian cyclicity and oestrus in lactating cows. Aust. Vet. J. 71:277-282.

Arthington, J. D., W. E. Kunkle, and A. M. Martin. 2002. Citrus pulp for cattle. Vet. Clin. North Am. Food Anim. Pract. 18:317-326.

Bergmeyer, H. U., and E. Bernt. 1974. Methods of Enzymatic Analysis. 2nd ed. Verlag Chemie, Weinheim, German Federal Republic.

Bergmeyer, H. U., and H. O. Beutler. 1985. Ammonia. Pages 454461 in Methods of Enzymatic Analysis. 3rd ed. H. U. Bergmeyer, ed. Verlag Chemie, Deerfield Beach, FL.

Callaway, T. R., and S. A. Martin. 1997. Effects of cellobiose and monensin on in vitro fermentation of organic acids by mixed ruminal bacteria. J. Dairy Sci. 80:1126-1135.

Drackley, J. K., T. R. Overton, and G. N. Douglas. 2001. Adaptations of glucose and long-chain fatty acid metabolism in liver of dairy 
cows during the periparturient period. J. Dairy Sci. 84(E. Suppl.):E100-E112.

Duffield, T., S. LeBlanc, R. Bagg, K. Leslie, J. Ten Hag, and P. Dick. 2003. Effect of a monensin-controlled release capsule on metabolic parameters in transition cows. J. Dairy Sci. 86:1171-1176.

Duffield, T., J. C. Plaizier, A. Fairfield, R. Bagg, G. Vessie, P. Dick, J. Wilson, J. Aramini, and B. McBride. 2004. Comparison of techniques for measurement of rumen $\mathrm{pH}$ in lactating dairy cows. J. Dairy Sci. 87:59-66.

Duffield, T. F., K. E. Leslie, D. Sandals, K. Lissemore, B. W. McBride, J. H. Lumsden, P. Dick, and R. Bagg. 1999. Effect of a monensincontrolled release capsule on cow health and reproductive performance. J. Dairy Sci. 82:2377-2384.

Duffield, T. F., D. Sandals, K. E. Leslie, K. Lissemore, B. W. McBride, J. H. Lumsden, P. Dick, and R. Bagg. 1998a. Effect of prepartum administration of monensin in a controlled-release capsule on postpartum energy indicators in lactating dairy cows. J. Dairy Sci. 81:2354-2361.

Duffield, T. F., D. Sandals, K. E. Leslie, K. Lissemore, B. W. McBride, J. H. Lumsden, P. Dick, and R. Bagg. 1998b. Efficacy of monensin for the prevention of subclinical ketosis in lactating dairy cows. J. Dairy Sci. 81:2866-2873.

Ferguson, J. M., D. T. Galligan, and N. Thomsen. 1994. Principal descriptors of body condition score in Holstein cows. J. Dairy Sci. 77:2695-2703.

Goodrich, R. D., J. E. Garrett, D. R. Gast, M. A. Kirick, D. A. Larson, and J. C. Meiske. 1984. Influence of monensin on performance of cattle. J. Anim. Sci. 58:1484-1498.

Green, B. L., B. W. McBride, D. Sandals, K. E. Leslie, R. Bagg, and P. Dick. 1999. The impact of a monensin controlled-released capsule on subclinical ketosis in the transition dairy cows. J. Dairy Sci. 82:333-342.

Grum, D. E., J. K. Drackley, R. S. Younker, D. W. LaCount, and J. J. Veenhuizen. 1996. Nutrition during the dry period and hepatic lipid metabolism of periparturient dairy cows. J. Dairy Sci. 79:1850-1864.

Hayes, D. P., D. U. Pfeiffer, and N. B. Williamson. 1996. Effect of intraruminal monensin capsules on reproductive performance and milk production of dairy cows fed pasture. J. Dairy Sci. 79:1000-1008.

Johnson, M. M., and J. P. Peters. 1993. Technical note: An improved method to quantify nonesterified fatty acids in bovine plasma. J. Anim. Sci. 71:753-756.

Littell, R. C., P. R. Henry, and C. B. Ammerman. 1998. Statistical analysis of repeated measures data using SAS procedures. J. Anim. Sci. 76:1216-1231.
Ludvigsen, C. W., J. R. Thurn, G. L. Pierpont, and J. H. Eckfeldt. 1983. Kinetic assay for D (-)-lactate, with use of a centrifugal analyzer. Clin. Chem. 29:1823-1825.

Mutsvangwa, T., J. P. Walton, J. C. Plaizier, T. F. Duffield, R. Bagg, P. Dick, G. Vessie, and B. W. McBride. 2002. Effects of a monensin controlled-release capsule or premix on attenuation of subacute ruminal acidosis in dairy cows. J. Dairy Sci. 85:3454-3461.

Nagaraja, T. G., C. J. Newbold, C. J. Van Nevel, and D. I. Demeyer. 1997. Manipulation of ruminal fermentation. Pages 523-632 in The Rumen Microbial Ecosystem. 2nd ed. P. N. Hobson and C. S. Stewart, ed. Blackie Academic \& Professional. London, UK.

Olsen, G. F. 1962. Optimal conditions for the enzymatic determination of L-lactic acid. Clin. Chem. 8:1-10.

Plaizier, J. C., A. Martin, T. Duffield, R. Bagg, P. Dick, and B. W. McBride. 2000. Effect of a prepartum administration of monensin in a controlled-release capsule on apparent digestibilities and nitrogen utilization in transition dairy cows. J. Dairy Sci. 83:2918-2925.

Ramanzin, M., L. Bailoni, S. Schiavon, and G. Bittante. 1997. Effect of monensin on milk production and efficiency of dairy cows fed two diets differing in forage to concentrate ratios. J. Dairy Sci. 80:1136-1142.

Richardson, L. F., A. P. Raun, E. L. Potter, C. O. Cooley, and R. P. Rathmacher. 1976. Effect of monensin on rumen fermentation in vitro and in vivo. J. Anim. Sci. 43:657-664.

Ruiz, R., G. L. Albrecht, L. O. Tedeschi, G. Jarvis, J. B. Russell, and D. G. Fox. 2001. Effect of monensin on the performance and nitrogen utilization of lactating dairy cows consuming fresh forage. J. Dairy Sci. 84:1717-1727.

SAS/STAT Software: Change and Enhancements Through Release 8.2 for Windows. 2001. SAS Institute, Inc., Cary, NC.

Stephenson, K. A., I. J. Lean, M. L. Hyde, M. A. Curtis, J. K. Garvin, and L. B. Lowe. 1997. Effects of monensin on the metabolism of periparturient dairy cows. J. Dairy Sci. 80:830-837.

Williams, C. B., P. A. Oltenacu, and C. J. Sniff. 1989. Refinements in determining the energy value of body tissue reserves and tissue gains from growth. J. Dairy Sci. 72:264-269.

Williamson, D. H., and J. Mellanby. 1974. D-3-hydroxybutyrate. Page 1836 in Methods of Enzymatic Analysis. H. U. Bergmeyer, ed. Academic Press, London, UK.

Yang, C. M. J., and J. B. Russell. 1993. The effect of monensin supplementation on ruminal ammonia accumulation in vivo and the numbers of amino acids-fermenting bacteria. J. Anim. Sci. 71:3470-3476. 